\title{
Notas sobre humanização e biopoder
}

A encomenda de escrever um texto para o encontro nacional de pesquisadores, que se destina a discutir a política de Humanização no Sistema Único de Saúde (SUS), soa-me bastante perturbadora.

Em primeiro lugar, porque não sou pesquisador, nem sequer possuo diploma de mestre.

Em segundo, não conheço absolutamente nada a respeito do Programa de Humanização do SUS, nunca participei dele. Tenho conhecimento de sua existência na gestão de José Serra, mas nunca soube como funcionava, tampouco como funciona atualmente.

Em terceiro, devo confessar que, apesar de ter tido formação cristã, ou talvez por ter tido - estudei em colégio religioso dos seis aos nove anos de idade -, sempre desconfiei da palavra humanização.

$\mathrm{Na}$ formação marxista, aprendemos a ter uma atitude crítica a respeito de todas as formas de cuidado, assim como dos diversos tipos de Estado.

Em outras palavras, nós, que éramos contra a propriedade privada, a família, o Estado e seus aparelhos ideológicos, estaremos reunidos nas terras onde o padre José de Anchieta criou sua Escola, para discutirmos a política de humanização exercida pela maior organização sanitária da América Latina, o SUS.

Talvez o padre José de Anchieta, além de inaugurar a literatura brasileira, tenha sido também um dos precursores do que hoje chamamos biopolítica no Brasil; sua obra teatral era direcionada para catequizar índios.

Um dos sentidos que Antonio Houaiss dá à palavra humanizar é amansar, amansar animais.

José de Anchieta também escreveu uma obra poética nos momentos em que se encontrava cativo dos índios tamoios, sem bíblia, sem terço, tentado pela beleza do corpo das mulheres que o rodeavam. Os poemas à virgem, escritos na areia, envoltos em erotismo, ajudaram nosso mentor a elaborar uma política de domínio de si, de seu corpo, que, segundo a tradição, morreu casto e criou corpos de paranoicos doces que marcaram fortemente a civilização brasileira.

A ação da organização militar constituída pelos jesuítas deixou marcas pelo Brasil, e foi precisamente em um local que levava seu nome e em um momento épico da história da saúde mental brasileira que nos confrontamos com o paradoxo do conceito de humanização.

* Apresentado durante o Seminário "Humanização do SUS em Debate", dias 25 e 26 de junho de 2008, em Vila Velha, ES. ${ }^{1}$ Escola Nômade de Filosofia. Rua Arruda Alvim, 112. Pinheiros, São Paulo, SP, Brasil. 05.410-020 lancetti@uol.com.br 
Em maio de 1989, intervínhamos na Casa de Saúde Anchieta e, metidos na batalha de opinião pública, anunciávamos a humanização do atendimento prestado aos internos do hospício. Pessoalmente, cheguei a declarar, em um programa de televisão, que estávamos praticando cuidados maternos primários, o que foi, como se pode imaginar, motivo de chacota dos companheiros.

Nosso líder David Capistrano, no mesmo programa de TV, afirmou que esses cuidados não se destinavam a manter ou a aperfeiçoar o hospital, mas a destruí-lo e a substituí-lo: "Não queremos fazer um manicômio bonzinho".

Se houve uma revolução psiquiátrica em Santos, como afirmou Guattari ao nos visitar, ela se deveu a um plano de ação que tinha como objetivo e alcançou uma ruptura com a psiquiatria e com a burocracia, e ainda ativou os aspectos não humanos da produção de subjetividade e efetuou forças não humanitárias da política e da saúde pública.

Talvez uma das frases que melhor sintetizem o paradoxo da humanização seja de Marx: A religião é o espírito de uma época sem espírito e o coração de um mundo sem coração, ela é o ópio dos povos.

De uma parte, humanizar é cuidar de outros, assistir; etimologicamente é estar do lado do outro, aliviar o sofrimento do povo, socializar, incluir.

Porém o cuidado, a geração de práticas e enunciações coletivas fundamentadas em relações de afeto, aquilo que, segundo Toni Negri e Michael Hardt, gera formas de comunismo espontâneo, escapa à prática técnica do cuidado, e os devires do comum estão ora em confronto, ora em conformidade com as formas de recuperação capitalistas e de reprodução da ordem social.

Negri e Hardt destacam três tipos de trabalho imaterial. Os dois primeiros referem-se à comunicação, à informática, à telemática, e o terceiro grupo de novos proletários é o dos trabalhadores afetivos.

No terceiro grupo é preciso distinguir a manipulação de afetos, no caso da indústria do entretenimento, e o trabalho de saúde fundamentado na produção de afetos.

Creio que é nesse contexto que poderíamos situar o debate da biopolítica e da humanização.

Voltando ao paradoxo do caritas como ópio dos povos e, ao mesmo tempo, como matéria de composição do tecido conjuntivo da sociedade, quero contar que, em nossas experiências santistas, achávamos que deveríamos levar a humanização, no sentido da solidariedade e da tolerância, até a máxima potência.

Elevar a solidariedade, a tolerância e o caritas a sua máxima potência de maneira que explodissem as formas humanas e piedosas de cuidar de outros.

$\mathrm{Na}$ época, fundamos o primeiro comitê de Combate à Fome e pela Vida, liderado por Betinho. Destaco que foi o primeiro porque, na ocasião, os dirigentes do PT desconfiavam da campanha.

A ideia era que, intensificando modos de coletivização, inclusive arcaicos, é possível estourar formas humanizadas ou demasiado humanas de cuidar de outros, como, por exemplo, o hospital psiquiátrico ou a retirada das equipes de saúde das escolas - que agora estão sendo reinstaladas, pela administração Kassab-Serra, em São Paulo, com base em um programa de rádio por demais antipático e humanístico, do jornalista Gilberto Dimenstein, que pretensiosamente se intitula Potencial Humano e que pressupõe que se deve educar para o mercado, e não investir para educar.

Acredito que, nas práticas de saúde, especialmente na saúde pública, somos obrigados, constantemente, a passar pelo meio, ou seja, pelo paradoxo da humanização como domesticação das pessoas e afirmação da vida com sua força de agregação e sua potência advinda de forças vitais prépessoais.

Todas essas questões são de alguma maneira prévias, embora inseridas na práxis e na poiesis sanitária ao lembrar que este encontro se destina a debater práticas de governo, práticas de Estado.

Félix Guattari, no maravilhoso livro Caosmose, afirma que os dois grandes riscos da vida no planeta são a degradação ambiental e a degenerescência das solidariedades sociais.

Suponho que o Programa Nacional de Humanização deve abranger toda a gama de serviços de Saúde, que vai dos hospitais às Unidades Básicas de Saúde, porém acredito que as ações desenvolvidas pelos serviços encravados no território e no espaço geográfico, onde as pessoas moram, requerem uma ação urgente. 
O capitalismo mundial integrado funciona produzindo subjetividades infantilizadas, produzidas por componentes humanos e não humanos; além da família, da frágil ação da escola e da incidência das políticas públicas na subjetividade, as religiões, cada vez mais embrutecedoras e menos espiritualizadas, deixam nossas populações urbanas entregues à manipulação de afetos da televisão, padecendo da escassez e regidas pela falta.

Sem dúvida, hoje, os fenômenos de violência adquiriram uma importância extrema, e nosso grande lumpesinato vive exposto aos maiores processos de embrutecimento psicológico - com a instituição família e as relações primárias devastadas e seu psiquismo e seus corpos regidos pela sociedade de controle.

A inserção dos profissionais de saúde nos domicílios, nos territórios geográficos e nos territórios existenciais mostra as mais variadas maneiras de violência. O documentário de Luciana Burlemaqui, Entre a luz e a sombra, exibido no festival de documentários "Tudo é Verdade", mostra como o sonho do Audi está no imaginário de cada ladrão, e como os ladrões de bancos ou os traficantes e sequestradores são figuras identificatórias de milhares de jovens brasileiros.

Eles ocupam, de alguma maneira, o lugar do revolucionário dos anos sessenta e setenta no imaginário de muitos meninos, meninas e jovens brasileiros. Cabe aos gestores da saúde pública e aos dirigentes sanitários reinventarem a polícia médica.

Aquilo que denominamos reinvenção da polícia médica é a intervenção do Estado no cuidado dos corpos, na intervenção nos territórios existenciais, produtores de subjetividade, ativando coletivos operantes, geradores de comunismo espontâneo e de invenção de vidas solidárias e criativas.

O maior feito do SUS nesse sentido é o Programa Saúde da Família (PSF). Com sua metodologia de equipes compostas por médicos generalistas, enfermeiros e agentes de saúde que moram no espaço geográfico, é a melhor estratégia para disputar a batalha da cidadania no território onde somente a Globo chega, isto é, o domicílio e os territórios existenciais.

Quando integralizada, a estratégia da família consegue tratar de pessoas drogadas, violentas, que partiram em linhas delirantes, alucinatórias, ou sobrecodificadas pela repetição mortífera do conjunto droga.

Biopolítica é uma forma de poder que regula a vida social desde seu interior no território; não é somente o cenário principal em que se desenvolvem a reforma e a revolução psiquiátrica, mas o campo de batalha da denominada reforma sanitária.

Assistir, aliviar o sofrimento, ativando o comum, é somente possível mediante uma ação civilizatória que opere na capilaridade onde o poder se incita, se suscita e se produz.

Evidentemente, não estamos propondo uma medicalização da violência.

A outra questão para a qual devemos alertar diz respeito à referência de pensadores da imanência, como Deleuze e Guattari, fazendo de seu pensamento uma representação.

Imagino que, em consequência das experiências de humanização, deve haver melhorado muito a relação dos profissionais de saúde com os usuários ou pacientes, porém, neste encontro, seria interessante observar indicadores de resultado.

Com estas notas pretendemos situar alguns dos paradoxos de uma prática sanitária fundamentada na defesa e na afirmação da vida.

A produção de saúde está imbricada com diversos modos de poder. A sua potência biopolítica é maior que o que supõem muitos gestores. 